\title{
A LAKÓHELYI SZUBURBANIZÁCIÓ HATÁSAINAK VIDÉKSZOCIOLÓGIAI VIZSGÁLATA DESZKEN
}

\author{
Vikor Zoltán Ágoston - Kis Krisztián
}

Absztrakt: A hazánkban jellemzöen a '90-es évektöl kibontakozó szuburbanizációs folyamatok jelentős hatással voltak, illetve vannak az érintett települések társadalmi-gazdasági helyzetére és fejlődésére. A szuburbanizáció hatására egy sajátos vidéki tér jön létre, ahol a városi és vidéki funkciók keverednek, illetve ütköznek. Tanulmányunkban e sajátos vidéki tér elemeit, föbb jellemzőit vizsgáltuk a lakóhelyi szuburbanizáció tükrében, a szegedi nagyvárosi településegyütteshez tartozó Deszk példáján. Célunk a vidéki teret meghatározó jellemzők vizsgálata volt Deszk két településrészén, ami lehetövé tette a szuburbanizáció hatásainak elemzését. Kutatásunk során a konstruktivista vidékszociológia megközelítésére támaszkodva vizsgáltuk a lokalitás, a vidékreprezentáció és a lakosok mindennapi életének jellemzöit. A kutatás alapján megállapítható, hogy a szuburbanizáció hatására megváltoztak, átalakultak a vidéki tér, a térhasználat, a helyi társadalom, a mindennapi élet, valamint a vidékreprezentáció jellemzői.

Abstract: The suburbanization processes that emerged from the 90 s in Hungary had a significant impact on the socio-economic situation and development of the settlements concerned. Under suburbanization, a specific rural space is created where urban and rural functions are mixed and collided. In our study, we examined the elements and the main characteristics of this particular rural space in the mirror of residential suburbanization, in the example of Deszk belonging to the metropolitan area of Szeged. Our aim was to examine the characteristics of the rural space in two parts of the settlement of Deszk, which made it possible to analyze the effects of suburbanization. Based on the approach of constructivist rural sociology, we studied the characteristics of locality, representation of rural and everyday life of the inhabitants. Based on the research it can be stated that the suburbanization has changed and transformed the characteristics of rural space, usage of space, local society, everyday life and representation of rural.

Kulcsszavak: szuburbanizáció, térhasználat, társadalmi változás, vidékreprezentáció

Keywords: suburbanization, usage of space, social change, rural representation

\section{Bevezetés, témafelvetés}

Az elmúlt évtizedekben a magyar vidék számos változáson ment keresztül, amelyek eredményeként jelentős mértékü társadalmi és gazdasági differenciálódás, mennyiségi és minőségi változás ment végbe a vidéki terekben. Ezen változások mögött álló folyamatok egyike a szuburbanizáció, ami a nagyvárosok közelében található, jó közlekedési adottságokkal rendelkező falvakat érinti. A hazánkban jellemzően a rendszerváltozást követően kibontakozó szuburbanizációs folyamatok jelentős hatással voltak, illetve vannak az érintett települések társadalmi-gazdasági helyzetére és fejlödésére.

Kovách (2012) véleménye szerint az ezredforduló korszakában a magyarországi települések társadalomszerkezetében strukturális jelentőségü változások zajlanak, amelyek közül a legnagyobb jelentőséggel a városokból a kisebb településekre történő migráció bír, melynek egyik célállomása a városi agglomeráció. Ily módon a városból vidékre vándorlás a jelenkori vidék egyik meghatározó tér és társadalom átalakító folyamatának tekinthető (Csurgó, 2013). A folyamat ugyanakkor nem most kezdődött, hiszen Csatári (2001) a magyar vidék és változásának '90-es években 
tapasztalt néhány jellegzetes földrajzi aspektusa kapcsán a vidékies térségek átalakulásának egyik fö irányaként jelöli meg az átalakult, szuburbán jellegü vidéki térkategória létrejöttét az eröteljes városias központok körül. Ezzel összefüggésben elmondható, hogy a szuburbanizáció az 1990-es és a 2000-es évek legnagyobb volumenü társadalmi térfolyamata volt hazánkban, és bár a 2000-es évtized közepétől dinamikáját tekintve visszaesés tapasztalható, jelentősége, társadalom- és térformáló szerepe máig meghatározó (Bajmócy, 2014).

Több szerző felhívja a figyelmet a szuburbanizáció többféle értelmezésére és megközelítésére, ami jelentösen befolyásolja a folyamat jellegének, okainak, hatásainak stb. megítélését és interpretációját (pl. Bajmócy, 2014; Kovách, 2012; Timár, 1999). Kocsis (2000) a szuburbanizáció mint folyamat alatt, az amerikai szociológiai irodalomhoz hasonlóan, szük értelemben, a középosztályi családoknak a város belső részeiböl annak peremére való nagy arányú költözését érti. Tágabb megközelítésben a szuburbanizáció mint az elővárosokat létrehozó folyamat: a városi népesség és tevékenységek decentralizációja, ami szerves részét képezi az urbanizációnak. Decentralizáció abban az értelemben, hogy a népesség, illetve a termelö és nem termelö tevékenységek, a nagyvárosok helyett az azokat övezö településekre települnek (Bajmócy, 2014; Tímár, 1999). Úgy is fogalmazhatnánk, hogy a szuburbanizáció mint a vidéki terek városi struktúrákba szerveződése, magában foglalja a városiak kitelepülését és a városi funkciók decentralizációját a városkörnyéki vidéki településekre (Kovách, 2012). Tekintettel arra, hogy e folyamat általában nem egyszerre érinti a városi tevékenységek teljes körét, ezért a szakirodalom megkülönböztet lakóhelyi, rekreációs, ipari, kereskedelmi stb. szuburbanizációt (Tímár, 1999). Csurgó (2013) felhívja a figyelmet arra, hogy a városkörnyéki vidék nem egyenlö az agglomerációval és a kiköltözés nem írható le csupán a szuburbanizáció jelenségeként, hanem a vidéki tér egy sajátos típusaként értelmezhető, ahol a szuburbanizálódás (városiasodás) és a retradicionalizáció elemei keverednek. A várost övező területek olyan dinamikus térként definiálhatók, ahol a városi funkciók ütköznek össze a vidéki funkciókkal. E sajátos vidéki tértípusban a városi szereplök, a kiköltözök fogyasztóként használják a vidéki teret, és ez hatással van a vidék átalakulására (Csurgó, 2013). A kiköltözök, a jobbára tehetősebb városiak megváltoztatják a célfalu társadalomszerkezetét, keresletük hatással van a helyi gazdaság és a szolgáltatások fejlödésére (Kovách, 2012).

Tanulmányunkban a lakóhelyi szuburbanizáció által az elmúlt évtizedekben jelentős mértékben érintett Deszk esetében végzünk összehasonlító elemzést a városból kiköltözök által lakott lakókert és a település fennmaradó belterületi része vonatkozásában. Ennek során vizsgáljuk a vidéki tér és társadalom átalakulásának, valamint a deszkiek mindennapi életének és a vidékreprezentációjának fontosabb elemeit. 


\section{A kutatási terület lehatárolása és rövid jellemzése}

Kutatásunk helyszíne Deszk község (1. ábra), ami a Szeged körül létrejött agglomeráció, a szegedi nagyvárosi településegyüttes része ${ }^{1}$, ahol 1990 után jelentős népességszám-növekedés történt, illetve az újabb lakóterületek kijelölése révén a belterület is számottevően bővült.

\section{1. ábra: Deszk község elhelyezkedése és közigazgatási területe}

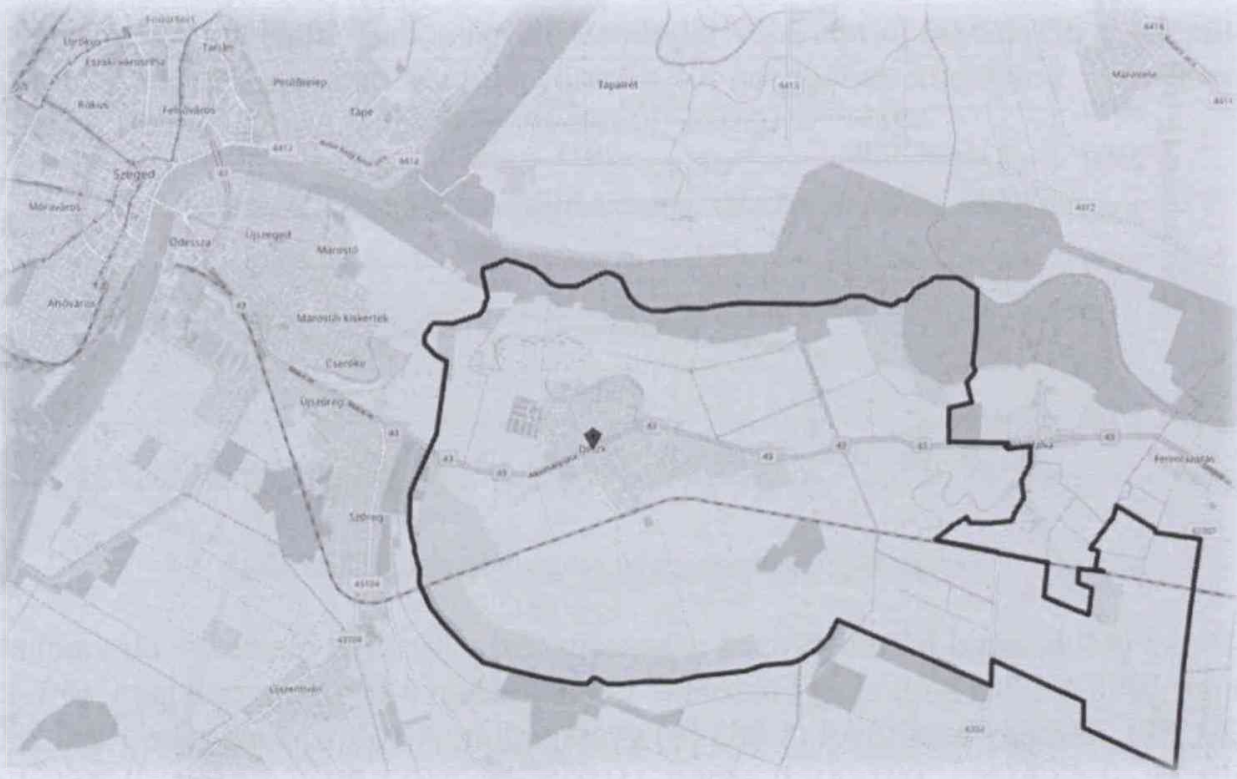

Forrás: https://data2.openstreetmap.hu/hatarok/hatarok.php?hatar=Deszk

Deszk Csongrád megye délkeleti részén, a Makóra vezető 43-as föút mentén, Szeged központjától mintegy 10 kilométerre, Szőregtől (Szeged délkeleti városrésze) 3 kilométer távolságra helyezkedik el. A település területe 5205 ha $\left(52,05 \mathrm{~km}^{2}\right)$, lakosainak száma 2017. január 1-jén 3838 fö volt, népsürüsége 73,7 fö $/ \mathrm{km}^{2}$, ami jóval a vidékiség hazai népsürüségi alapkritériumának számító 120 fö/ $\mathrm{km}^{2}$-es népességkoncentrációs határérték alatt van, így vidéki településnek számít, ami a jelentős városi nyomás, a beépített terület és a lakosságszám növekedése ellenére, több vonatkozásban magán viseli a vidékiség jegyeit. Deszk kedvező közlekedés-földrajzi helyzete, Szeged közelsége a település életében, illetve kutatásunk szempontjából is nagy jelentőséggel bír, hiszen a nagyvárosból kiköltözők egyik célterülete e kétnyelvủ szuburbia (a település szerb neve: Деска).

$\mathrm{Az}$ utóbbi évtizedek statisztikai adatai alapján Deszk a növekvő lélekszámú települések közé sorolható (2. ábra). Lakossága 2017-ben 3838 fö volt, melynek

\footnotetext{
' A településegyüttest Szeged és a szomszédságában található 13 község (Algyő, Bordány, Deszk, Dóc, Domaszék, Ferencszállás, Klárafalva, Kübekháza, Röszke, Szatymaz, Tiszasziget, Újszentiván és Zsombó), valamint Sándorfalva városa alkotja (KSH, 2014).
} 
95\%-a magyar nemzetiségü (TeIR, 2018). A szerb nemzetiségủ lakosok száma napjainkban már nem számottevő, arányuk 2-3\% (TeIR, 2018). A külterületi lakosság aránya sem jelentős $(1,5 \%)$, néhányan tanyán, nagyobb részük a településhez szorosan kapcsolódó külterületi zártkertes övezetben él (TeIR, 2018).

\section{2. ábra: Deszk lakónépességének változása 1870 és 2017 között}

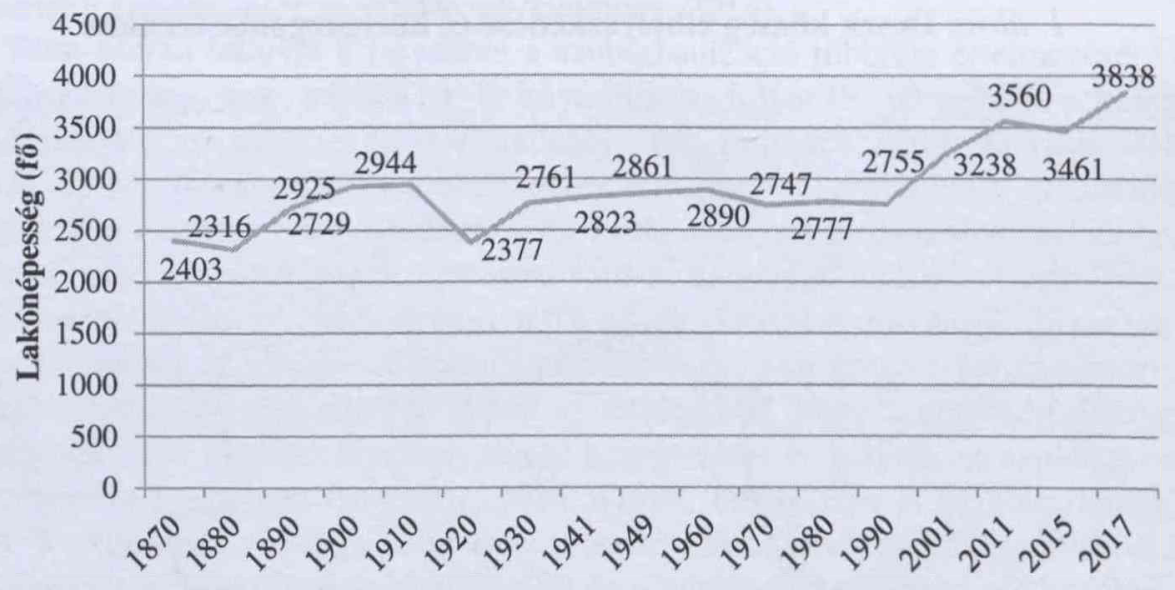

Forrás: http://nepesseg.com/csongrad/deszk (2018.05.12.)

Az utóbbi majd három évtized népességszám változását elemezve elmondható, hogy 1990-től 2017-ig, azaz huszonhét év távlatában a lakosság csaknem 40\%-kal (39,3\%), mintegy ezer fővel (1 083 fö) gyarapodott. A változás mértéke 1990-2001 között $+1,48 \% / e ́ v, 2001-2011$ között $+0,95 \% / e ́ v, 2011-2015$ között $-0,7 \% / e ́ v$ és 2015-2017 között $+5,31 \%$ /év volt. Ez a növekedés azonban nem a pozitív természetes szaporodásnak, hanem a pozitív vándorlási különbözetnek köszönhető. A KSH (2014) hazai agglomerációkra irányuló kutatása szerint a 2001 és 2012 közötti időszakban a szegedi nagyvárosi településegyüttesben a városkörnyék legkedveltebb céltelepülése, ahová a kitelepülők közül legtöbben költöztek, Deszk volt. Az ezredfordulótól nézve a 2013-as év kivételével nem volt olyan időszak, amikor negatív vándorlási különbözet lett volna jellemző a településre, miközben a természetes szaporodás egyenlege ugyanezen időszak alatt mindössze 5 évben mutatott néhány fös pozitívumot.

A vándorlási folyamatokkal összhangban a lakás- és a gépkocsiállomány nagyságának folyamatos növekedése is jól illusztrálja a település (lakossági) szuburbanizáció folyamatában való érintettségét. Ezzel összefüggésben elmondható, hogy a millenniumot követően a lakásállomány 262 , a gépkocsik száma 586 darabbal bővült, ami az előbbi esetben 23,8 , utóbbiban 90,7 százalékos növekedést jelent (KSH, 2018).

A szuburbanizáció hatásaival összefüggésben említhető, hogy a helyi társadalomra az elöregedés jellemző, de közel sem olyan mértékben, mint járási, megyei, regionális vagy országos szinten. Az öregedési mutató (az időskorú, 60 év 
feletti és a fiatal, 0-14 éves népesség aránya) értéke 2015-ben 138,7\% volt, ami csaknem 40 százalékponttal kedvezőbb, mint az ehhez legközelebbi országos érték. A település lakosainak jövedelmi helyzetét jól mutatja az egy lakosra jutó összes nettó jövedelem összege, ami 2014-ben 799977 Ft volt, amely érték, igaz csak kis mértékben, 10-20 ezer forinttal, de meghaladta még az országos és járási szintek fajlagos összes nettó jövedelmét is. Előbbiek mindenképpen összefüggésbe hozhatók a Deszkre kiköltözők demográfiai és jövedelmi helyzetével.

Vizsgálatunk helyszíne a Szeged környéki Deszkre terjed ki, ahol a nagyvárosból kitelepülő lakosság előszeretettel választja új lakhelyéül a település Szegedhez közeli, az ezredforduló környékétől kezdődően kialakított Marosmenti lakókert (továbbiakban lakókert) övezetét (3. ábra).

\section{3. ábra: A vizsgált településrészek elhelyezkedése Deszken}

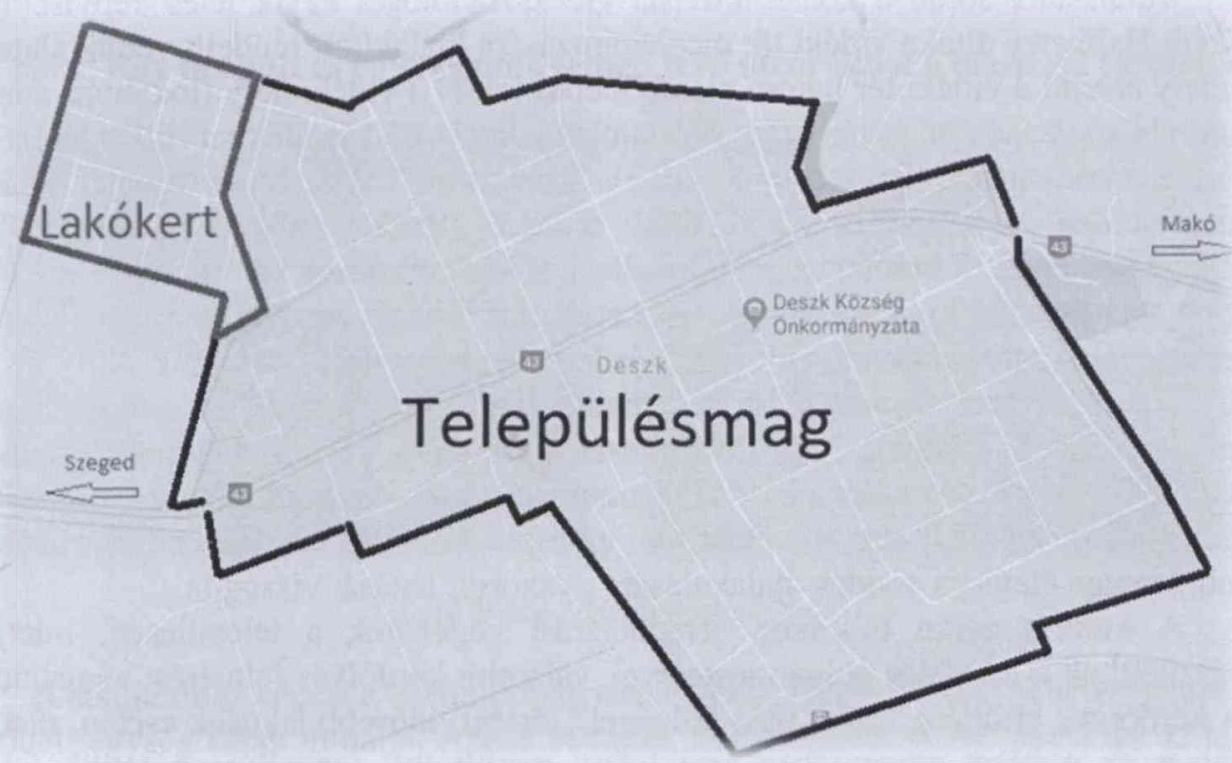

Forrás: www.google.com/maps alapján saját szerkesztés

Ennek következtében napjainkra egy újonnan kialakuló és egyre inkább beépülő, benépesülő településrész jött létre, amely több vonatkozásban magán viseli a szuburbanizáció hatásait, megkülönböztetve azt a település más részeitől, a hagyományos falusias jellegü településrészektől, amelyeket a továbbiakban, összefoglalóan településmagnak nevezünk.

\section{A kutatás célja és módszere}

Kutatásunk célja annak vizsgálata, hogy milyen jellemzői vannak a „helyivé lett” (beköltözők, városból kiköltözők, lakókerti népesség) és a helyiek (őslakosok, telpülésmagban élők) térhasználatának, társadalmának, mindennapi életének és vidékreprezentációjának. 
A kutatás hipotézisei:

1. A lakókert lakossága és a település egyéb területeinek lakossága között jól kimutatható társadalmi-gazdasági különbség figyelhető meg. A lakókert lakói a településmag lakóihoz képest fiatalosabb, magasabban kvalifikált, tehetősebb társadalmi réteg képét mutatják;

2. A lakókertben élők jelentős hányada a közeli nagyvárosból kiköltözöttekböl áll. Ebből kifolyólag nagyobb mértékben kötődik Szegedhez, mint a településmag lakossága. Ez a lakosok napi térhasználatából, a szolgáltatások igénybevételének helyeiből is kitünik;

3. A lakókert és a településmag lakossága egymástól különböző vidékképpel rendelkezik; más a vidékről alkotott elképzelésük (vidékreprezentációjuk), és másként élik meg a vidéki (falusi) mindennapjaikat.

Kutatásunk során a konstruktivista vidékszociológia egyik jeles képviselője, Keith Halfacree által a vidéki tér meghatározására kialakított modellt vettük alapul, amely szerint a vidéki tér három elemböl épül fel: (1.) vidéki hely (lokalitás, ami a különbözö társadalmi és térbeli gyakorlatokat jelenti), (2.) a vidék reprezentációja és (3.) a mindennapi élet (Csurgó, 2013). Kutatásunk céljának és hipotéziseinek megfelelően a szuburbanizáció által érintett Deszk, mint vidéki település jellegzetességeinek bemutatására a lokalitás, a reprezentációk és a mindennapi élet főbb sajátosságait kívántuk felmérni és értékelni. Ennek megfelelően vizsgáljuk a térhasználat, a társadalom (demográfiai jellemzők, képzettség, gazdasági aktivitás és jövedelmi helyzet), a mindennapi élet (beilleszkedés, közösségi élet, szolgáltatások igénybevétele), illetőleg a vidékreprezentáció főbb jellegzetességeit mindkét településrész vonatkozásában. Vizsgálatunkban támaszkodtunk Csurgó Bernadett (2013) munkájára, aki a városból vidékre költözők vidékreprezentációját, mindennapi életét és a vidék átalakulására gyakorolt hatását vizsgálta.

A kutatás során többszöri terepbejárást végeztünk a településen, interjút készítettünk a település polgármesterével, valamint kérdőíves felmérést végeztünk. A kérdőívek kitöltése „önkitöltős jelleggel” történt. Idősebb lakosok esetén, illetve abban az esetben amennyiben erre igény merült fel, személyesen tettük fel a kérdéseket. Területenként (lakókert és településmag) 50-50 kérdőív lekérdezése volt a cél, így összesen 100 kérdöív került kitöltésre. A kérdőíves felmérés alapegysége a lakás volt, így a lakókert területén minden második, a településmag területén minden huszonötödik lakást kérdeztük meg. Amennyiben, az adott lakás lakatlan volt, nem voltak otthon vagy nem kívánták kitölteni a kérdőívet, a soron következő lakásra esett a választás.

\section{A lokalitás jellemzőinek vizsgálata}

A lokalitás(ok) kapcsán a településképet, a lakást, annak szük környezetét és a lakosságot, annak településrészi jellemzőit vizsgáljuk és hasonlítjuk össze. 


\subsection{A térhasználat vizsgálata}

A városiak vidéki térre gyakorolt hatásának egyik jellegzetes eleme a vidéki tér átalakulása. Csurgó (2003) vizsgálatában leírtakhoz hasonlóan, az utóbbi évtizedekben Deszk esetén is megfigyelhető volt a földhasználat funkcióváltásával történő belterület bővítés. A lakókert kapcsán ez az ezredforduló környékére tehető, amikor a külterületi szántóföldek belterületté nyilvánításával megkezdődött a mai településrész kialakítása. (A lakókert területe megközelítőleg 25 ha, ezzel szemben a településmag területe 250 ha.) Megfigyeléseink szerint napjainkra, a kialakított porták megközelítőleg $50 \%$-a került beépítésre (4. ábra). A területet gyakran említik úgy a helybeliek, mint „újosztás”, „kertváros” vagy éppen, mint „lakópark”. Ez utóbbi megnevezés jogos, hiszen számos tekintetben hasonlít a hazai lakóparkokhoz. Hegedüs (2009) véleménye szerint azonban a terület maximum „állakóparknak” nevezhető, ugyanis nincs elkerítve és szolgáltatásokat sem nyújt lakói számára.

\section{4. ábra: Egy beépült és egy beépülő félben lévő utcarészlet a lakókert területén}
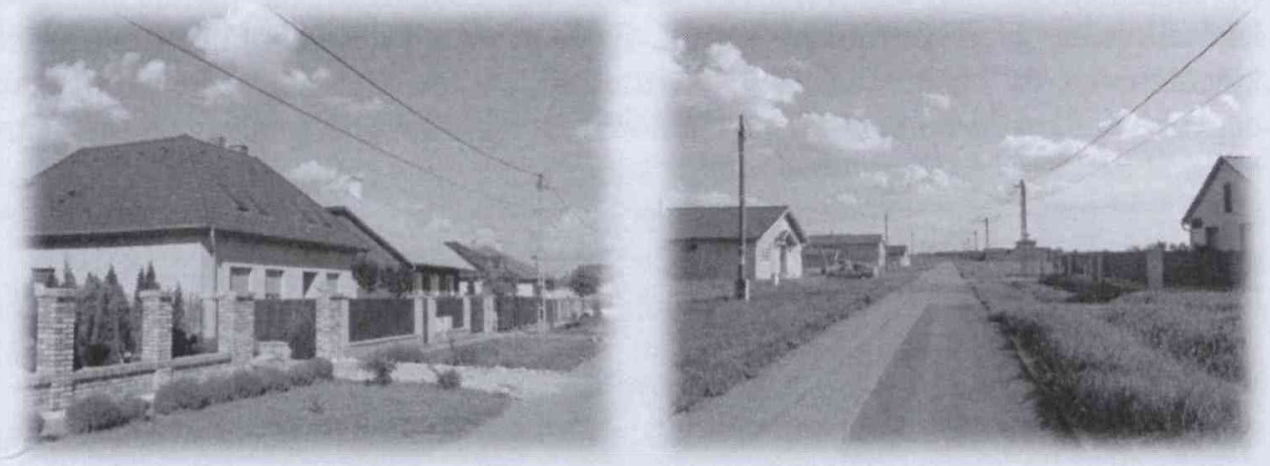

Forrás: Vikor Zoltán Ágoston (2018)

A lakókerthez képest a településmag természetszerüleg egy sokkal heterogénebb területi egység képét mutatja. Annak ellenére, hogy területe és beépítettsége az idő folyamán növekedett (a 20. század különböző időszakaiban kialakult településrészeket a településmag részének tekintjük), lakásállományában meghatározóak a típusterv alapján készült sátortetős kockaházak. A településközpont ad helyet az intézményeknek, boltoknak és egyéb szolgáltató helyeknek, amelyek zömmel ezen a területen koncentrálódnak (5. ábra). 


\section{5. ábra: Sátortetős kockaházak a fơútvonal mentén és a községháza a falu központjában}
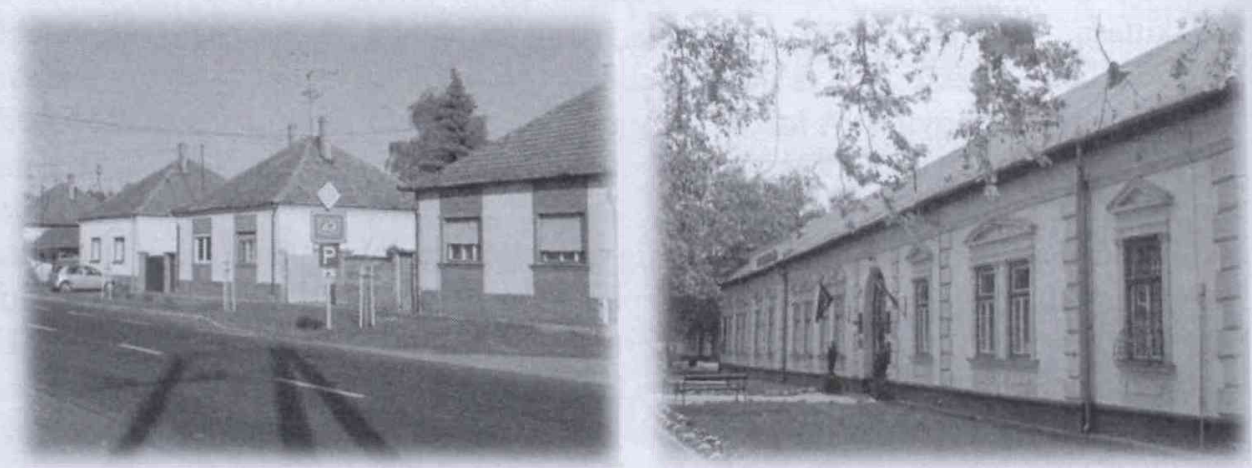

Forrás: Vikor Zoltán Ágoston (2018)

Előbbiekben utaltunk rá, hogy a lakosság növekedésével párhuzamosan a lakásállomány is folyamatosan bővült. $\mathrm{Ez}$ a növekedés egyértelmüen a lakókert kiépülésének és benépesülésének köszönhetö. A település egészét tekintve két nagyobb építkezési hullámot lehet elkülöníteni. Egyrészt a településmagra jellemző az 1961 és 1980 között épült sátortetős kockaházak nagy aránya, mely elsősorban a régi házak helyén történő új házak építésére utal. Ezzel szemben a lakókert területén meghatározó az ezredfordulótól jelentkező építési kedv, mely már egyértelműen a beköltöző lakossághoz köthető. Ez utóbbi területen nem jelentős a 2000 előtt épült házak aránya (14\%). Meghatározó részük az ezredfordulót követő tíz évben (70\%), illetve az azt követő években épült (16\%).

A vizsgálat eredményei alapján egyértelmü összefüggés figyelhető meg a házak építési ideje és azok alapterülete között. Általánosságban elmondható, hogy egyre nagyobb alapterületü házak építése a jellemző. Az átlagos alapterület a településmag területén $116 \mathrm{~m}^{2}$, a lakókert esetén $140 \mathrm{~m}^{2}$ körül alakul.

Korábban bemutattuk, hogy a település népességének növekedése alapvetően a pozitív vándorlási különbözetnek köszönhető, azaz a lakosok jelentős része más településről költözött Deszkre. Válaszadóink 45\%-a születése óta él a településen, tehát 55\%-uk, valamely más helységből költözött Deszkre, jellemzően (68\%) Szegedröl. A lakókert esetén ez az arány $90 \%$ feletti. Legtöbb esetben a házasságkötés, életmódváltás és a Szegedhez való közelség miatt költöztek a településre. A településmag esetén a „beházasodás” a legmeghatározóbb, a lakókert esetén a Szegedhez való közelség, életmódváltás, családalapítás, új családi ház iránti igény a leggyakoribb indok. Továbbá e kertvárosi településrészen megjelennek azok a korábbi kutatásokban már kimutatott eredmények („új erőforrások”) is, melyek szerint a természeti környezet, a nyugalom, csend iránti igény, igen fontos motivációs tényezők a szuburbanizáció tekintetében (Bajmócy, 2003; Csurgó, 2013; Dövényi-Kovács, 1999; Frumkin, 2002; Kovách, 2007; Tímár, 1999).

A település teljes területére jellemző a rendezett utcakép. A házak szükebb környezetét vizsgálva azonban különbségek figyelhetők meg, melyek összefüggésbe 
hozhatók a két településrészen lakókkal, avagy a társadalmi státusszal, a mindennapi életvitellel. A lakókert területére sokkal inkább a kertvárosi életforma, mint a hagyományos értelemben vett falusi életforma jegyei jellemzőek. A kertvárosias jelleget erősíti, hogy a házakat általában gondosan ápolt pázsitos udvarok, virágoskertek, dísznövények, burkolt felületek veszik körül. Ezzel szemben a hagyományos falusi életformára utal, hogy a településmag területén, a lakóépületen és a garázson kívül sok esetben ól, mühely, góré, veteményes, gyümölcsös is megtalálható a telkeken.

A morfológiai különbségek a települést megjelenítő müholdképeken is felismerhetőek. Szembetűnő a porták méretbeli különbsége is. Jól látható a lakókert $800 \mathrm{~m}^{2}$-es és a településmag (korábban kialakult részein az) $1500 \mathrm{~m}^{2}$ telkei közti különbségek. Ez minden bizonnyal annak a funkcióváltásnak, foglalkozás és életvitel változásnak is köszönhető, mely révén napjainkban már nincs szükség nagy kertre, ahol a konyhakerten kívül az esetlegesen piacra szánt növények is megtermelhetőek. A müholdképek segítségével a településmag területén jól látható még az a mintegy tucatnyi helyi termelö is, aki fóliasátrakban virág vagy zöldségtermesztéssel foglalkozik (6. ábra).

\section{6. ábra: A településmag múholdképe (részlet)}

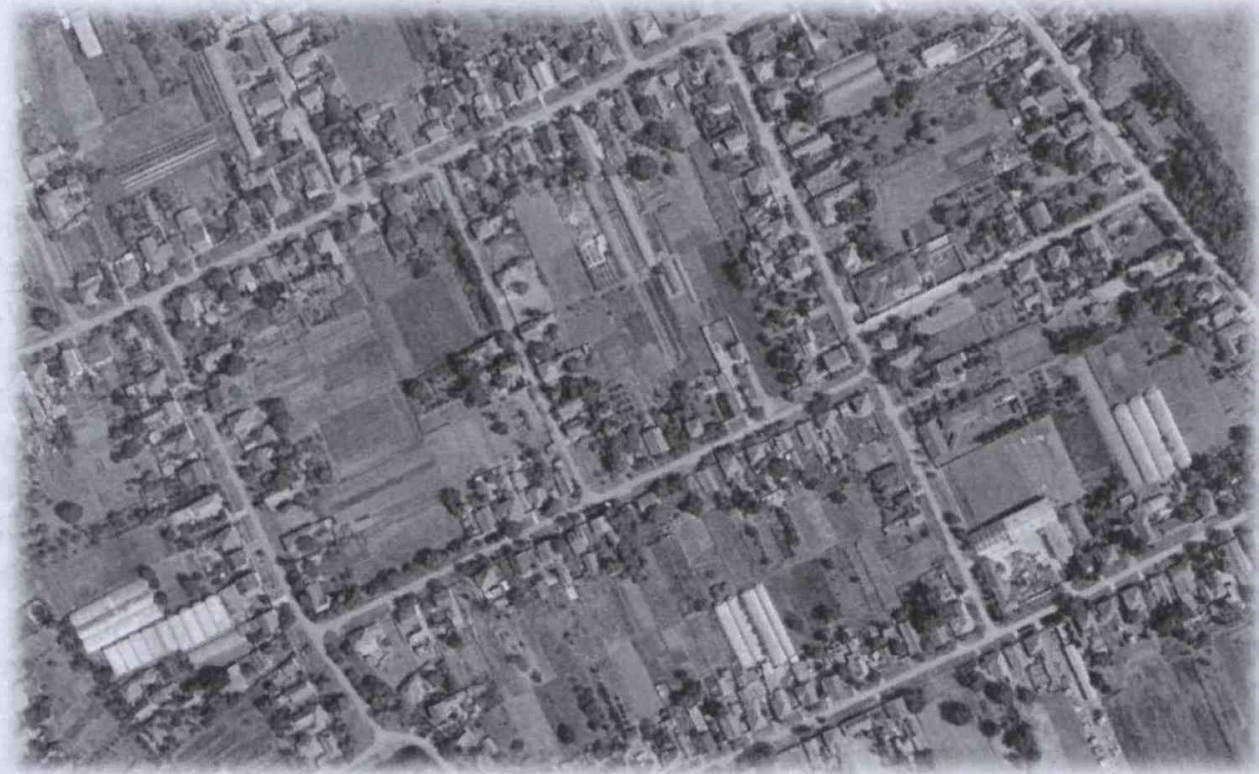

Forrás: Google Térkép (2018)

Továbbá a lakókert esetén a házak udvarán jellegzetes kép a többnyire kör alakú gyerekmedencék látványa, melyből a gyermekes családok nagyarányú jelenlétére következtethetünk (7. ábra). 


\section{7. ábra: A lakókert müholdképe (részlet)}

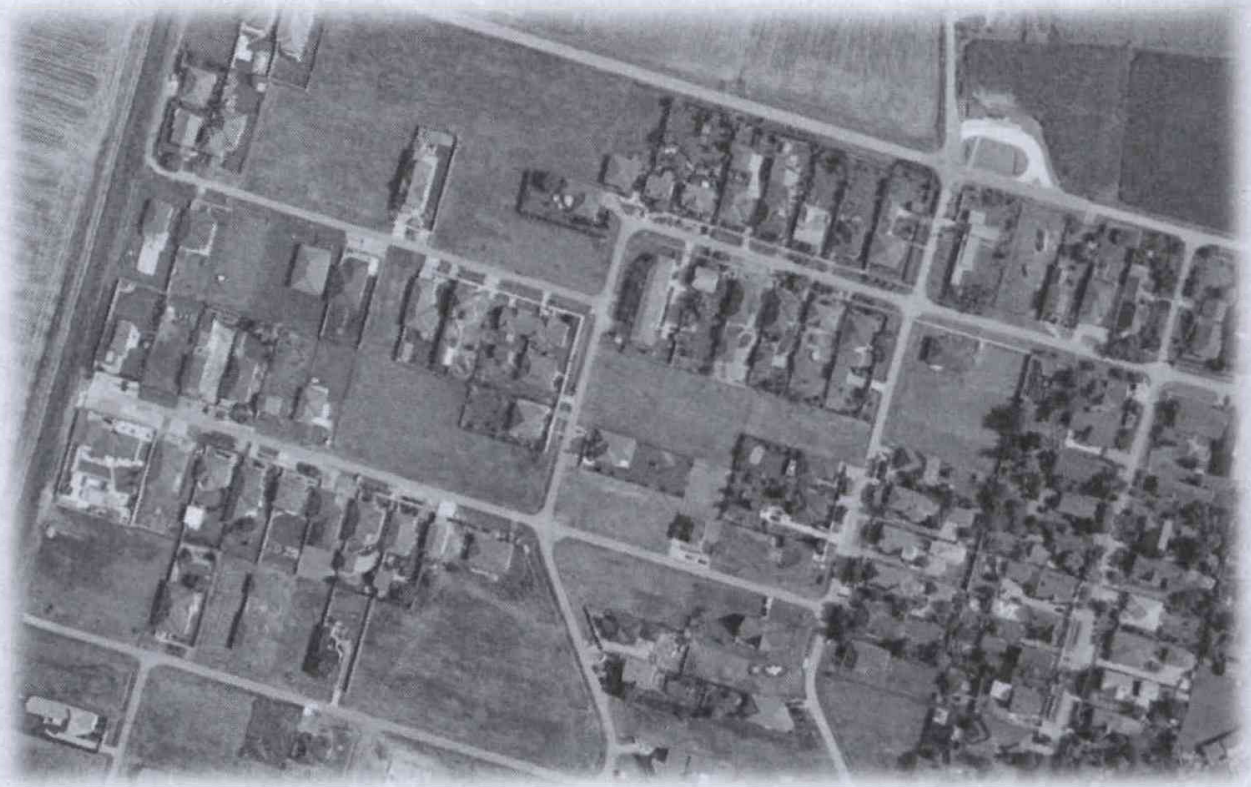

Forrás: Google Térkép (2018)

\subsection{A társadalom vizsgálata}

A következőekben az életkor, az iskolai végzettség, a gazdasági aktivitás és a jövedelmi viszonyok segítségével mutatjuk be a két terület lakosságának jellemzöit.

A vizsgálat adatai szerint 36,5 év volt az átlagos életkor a település egészén. Ez 4,5 évvel alacsonyabb, mint a 2017. évi teljes sokaságra vonatkozó átlagos életkor, ami 41 év (KSH, 2018 - adatkérés). Ez a különbség valószínüleg az idősebb lakosság körében jellemző alacsonyabb válaszadási hajlandóságnak és a kutatás módszerének tudható be, mely szerint a településmag területén arányaiban kevesebb lakás, így lakos lett lekérdezve, mint a lakókert területén. A két településrészen lakók átlagos életkora a következő: településmag esetén 44 év, lakókert esetén 29 év. Ez utóbbi településrész jóval alacsonyabb értéke a fiatalabb korosztályok magasabb arányának köszönhető. Az 1. táblázat jól mutatja, hogy a lakókertben a 0 és 20 év közti, valamint a 30-50 év közti lakosok aránya a meghatározó. A fiatalos korszerkezetre utal az is, hogy vizsgált háztartásokban alig volt 60 évnél idősebb lakos. Ezzel szemben a településmagban majdnem minden negyedik ember 60 évnél idősebb volt. Megfigyelhető, hogy a területenkénti korszerkezet összhangot mutat az egy háztartásban élők számával, ami a település egészére nézve 3,5 főt jelent. Ez az érték a lakókert esetén 3,9 fö, ami a gyermekes családok magas számából adódik. A településmag ugyanezen értéke 3,1 fő/lakás, ami az egy-két fős háztartások nagyobb arányából is következik. 


\section{1. táblázat: A két településrész lakosságának korcsoportonkénti megoszlása}

(\%)

\begin{tabular}{|l|l|l|l|l|l|l|l|l|l|}
\hline Településrész & $\mathbf{0 - 1 0}$ & $\mathbf{1 1 - 2 0}$ & $\mathbf{2 1 - 3 0}$ & $\mathbf{3 1 - 4 0}$ & $\mathbf{4 1 - 5 0}$ & $\mathbf{5 1 - 6 0}$ & $\mathbf{6 1 - 7 0}$ & $\mathbf{7 1 - 8 0}$ & $\mathbf{8 1 - X}$ \\
\hline településmag & 9,7 & 12,5 & 11,4 & 10,8 & 15,9 & 15,9 & 17,0 & 6,3 & 0,6 \\
\hline lakókert & 27,3 & 17,3 & 6,6 & 20,0 & 22,1 & 4,1 & 2,6 & 0,0 & 0,0 \\
\hline
\end{tabular}

Forrás: Kérdőíves felmérés (2018)

Az emberek képzettségi szintje hatással van a munkavállalás lehetőségére, ezáltal a jövedelmi helyzetre, a társadalmi státuszra, a szabadidő eltöltésére, így a mindennapjaikra. A kutatás iskolázottságra vonatkozó eredményeit a 8. ábra szemlélteti. (A lekérdezett háztartásokban élő, 24 évet meghaladó lakosok végzettségét figyelembe véve.) A lakókert esetén, az érintett lakosok több mint $60 \%$ ának van felsőfokú végezettsége, olyan személy pedig nem is akadt, akinek ne lett volna valamilyen középiskolai végzettsége. Ezzel szemben a településmag területén a középszintü végzettséggel rendelkezők aránya a legmeghatározóbb és az előző területhez képest jóval kisebb a felsőfokú végzettséggel rendelkezők aránya (24\%).

\section{8. ábra: A 24 éven felüliek iskolai végzettségének megoszlása}

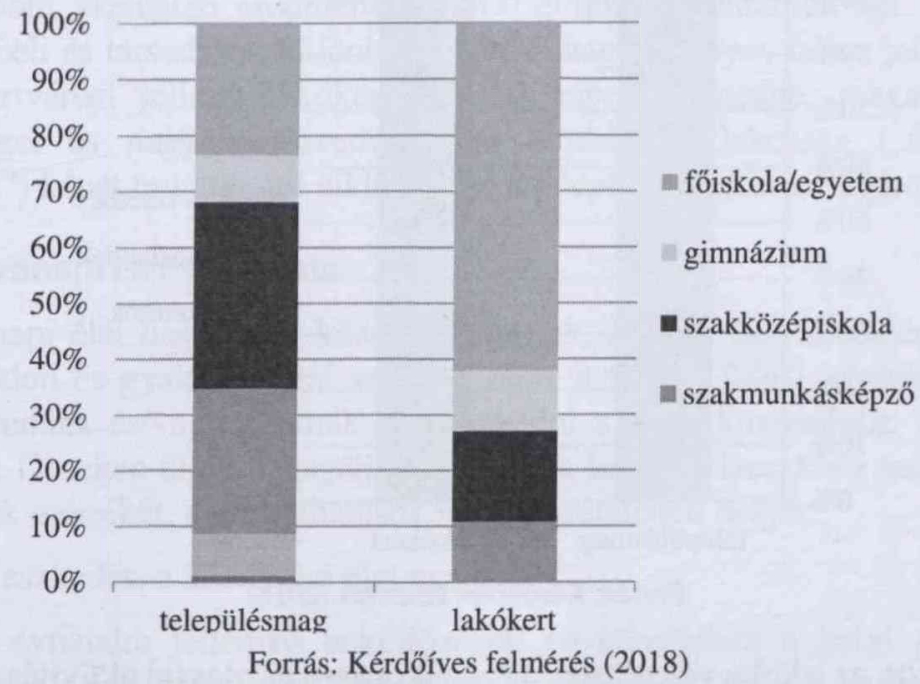

A foglalkoztatási szerkezetet tekintve (2011-es adatok alapján) a lakosság meghatározó része, $66 \%$-a a tercier szektorban, $28 \%$-a a szekunder szektorban és mindössze $6 \%$-a a primer szektorban dolgozik (TeIR, 2018). A foglalkozási szerkezet tekintetében a két településrész közötti lényeges különbség, hogy a lakókert esetében csupán 3 fő volt a primer szektorba sorolható, valamint a tercier szektor dominanciája mellett jellemző a kvaterner szektor jelenléte is. Ezzel szemben a településmag területére az országos trendeknek megfelelő adatok jellemzőek.

A lakosságot vizsgálhatjuk gazdasági aktivitás szerint is. A megoszlást mutató 9. ábra a megkérdezetteken túl, a velük egy háztartásban élőkre is, összesen 338 
före, a település össznépességének mintegy $9 \%$-ára vonatkozóan tartalmazza az adatokat. A település egésze esetén a népesség 37\%-a folytat kereső tevékenységet. A gazdaságilag aktívak tekintetében, a fiatalabb korszerkezettel rendelkező lakókerti részen az aktív keresők néhány százalékponttal nagyobb aránya jellemző. Ezzel szemben munkanélküli kategóriába csupán egy lakos sorolható, nem úgy, mint a településmag területén, ahol ez $6 \%$ körül alakul. Abból adódóan, hogy az inaktív keresők csoportját nyugdíjasok és a gyermeküket nevelő, nem dolgozó szülők alkotják, előre sejthető, hogy területenként jelentős különbségek figyelhetőek meg. A településmag esetén az inaktívak aránya 34\%, 24 százalékponttal magasabb, mint lakókerti szinten. Az első területen ez elsősorban a nyugdíjasok nagy számából következik, míg a lakókerti részen a csoportot föként a GYED-en vagy GYES-es lévő szülők alkotják. Az előzőekből következően az eltartottak aránya a lakókerti részen kimagasló $(51 \%)$, duplája a településmag értékének, vagyis megközelítőleg minden második lakos az eltartottak közé sorolható.

\section{9. ábra: A lekérdezett háztartásokban lakók gazdasági aktivitásának megoszlása}

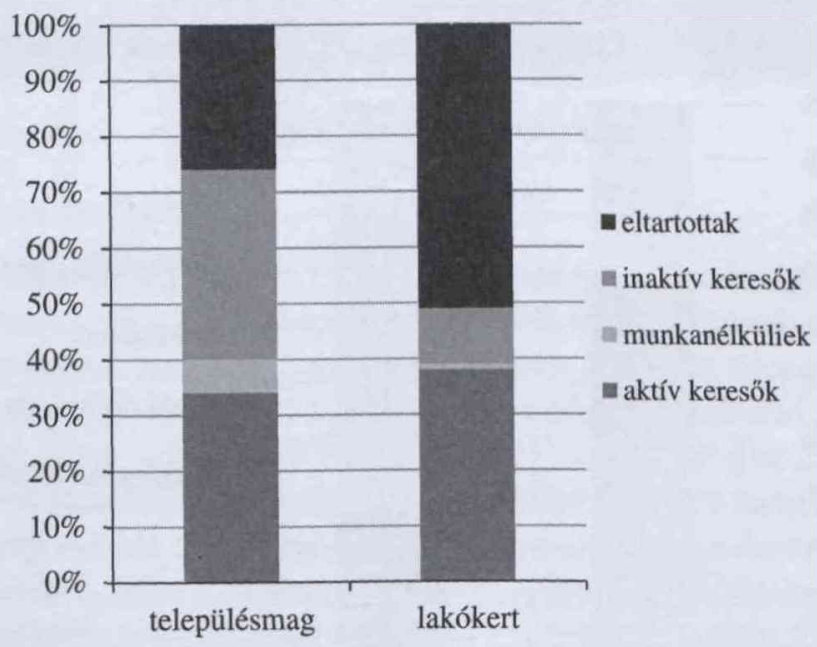

Forrás: Kérdőíves felmérés (2018)

Az életkor, az iskolai végzettség, a foglalkozás, a gazdasági aktivitás sok esetben meghatározó a jövedelem nagysága szempontjából. A 10. ábra a kérdőívet kitöltők jövedelem szerinti megoszlását mutatja a két településrész vonatkozásában. (Csak a kérdőívet kitöltők jövedelmére kérdeztünk rá, vagyis az adatok nem a lekérdezett háztartások/családok jövedelem megoszlását mutatja.) Az adatok alapján a lakókert lakosai egyértelmüen magasabb jövedelemmel rendelkeznek. A válaszadók több mint a fele rendelkezik legalább havi $150000 \mathrm{Ft}$ összegü jövedelemmel, míg a településmag esetén ez csak minden ötödik esetben mondható el. Ennél magasabb fizetési kategóriák is egyértelmüen a lakókerti részre jellemzőek, nem úgy, mint az ennél alacsonyabb kategóriák, melyek a településmag viszonylatában a meghatározóak. 


\section{0. ábra: A megkérdezett lakónépesség megoszlása jövedelemkategóriánként}

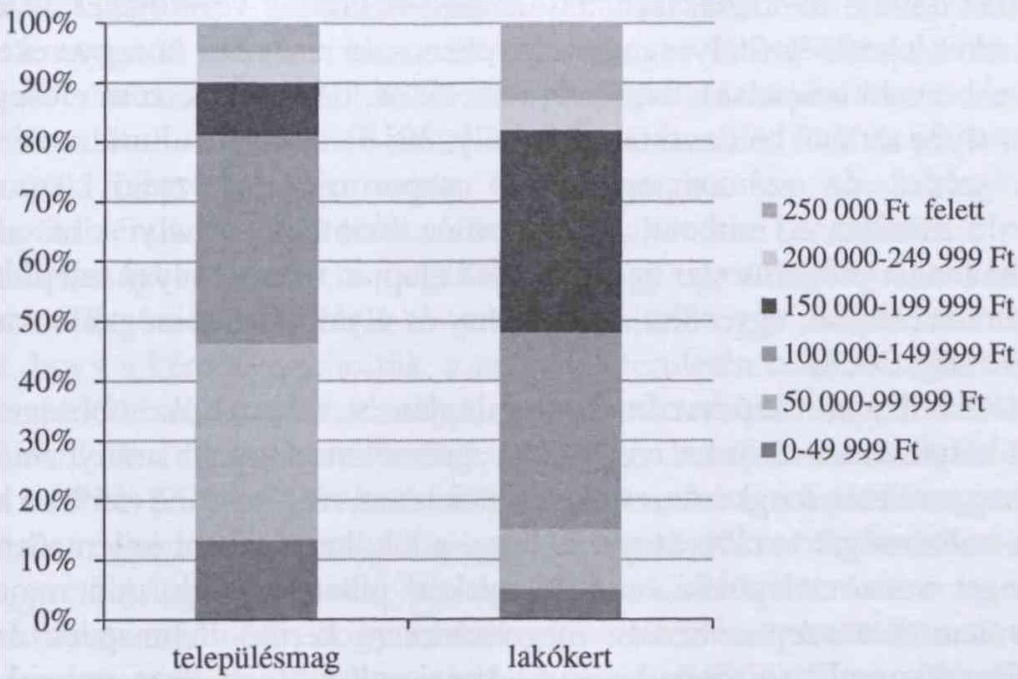

Forrás: Kérdőíves felmérés (2018)

$\mathrm{Az}$ előbbi vizsgálati eredmények egyértelműen rámutatnak két településrész közötti térbeli és társadalmi különbségekre. A hagyományos falusi jellegtől eltérő, azaz a kertvárosi jellegü lakókertben élők egy fiatalosabb, magasabb iskolai végzettséggel és nagyobb jövedelemmel rendelkező lakosság („településrészi társadalom”) képét mutatja, jól elkülönülve a településmag lakosságától.

\section{A mindennapi élet vizsgálata}

A mindennapi élet összetevői között vizsgáljuk, hogy a két településrész lakosai milyen módon és gyakorisággal vesznek részt a falu, a falusi közösség életében, mennyire tudnak és/vagy akarnak beilleszkedni a helyi közösségbe, illetve, hogy szeretnek-e Deszken élni? Vizsgáljuk továbbá a lakosok Deszkhez való viszonyát, kötődésének mértékét, a szolgáltatások igénybevételének helyét.

\subsection{A beilleszkedés, a közösségi élet vizsgálata}

Az elmúlt évtizedre jellemző beköltözések következtében a helyi gyökerekkel, kapcsolatokkal és ismeretségekkel nem rendelkezők száma megnőtt. Fontos kérdéssé vált, hogy a község vezetése és a helyi lakosok, valamint a településre költözők hogyan viszonyulnak egymáshoz és a település egészéhez. A lakókert területe ez esetben különösen érdekes, hiszen felnőtt lakossága szinte teljes egészében beköltözöttekböl áll.

Úgy véljük, hogy egy település vezetése számára mindig is fontos, hogy megszólítsa az új lakosokat. A polgármester úr elmondása szerint az önkormányzat, a Faluház, továbbá az oktatási intézmények, kisebb-nagyobb sikerrel, törekszenek az újonnan betelepülők megismerésére és szimpátiájuk elnyerésére. Az eddigi tapasztalatok alapján elmondható, hogy nehéz megszólítani őket, nehéz felkelteni az 
érdeklödésüket a helyi rendezvények iránt, valamint nehéz meggyőzni öket, hogy gyermekeiket a helyi óvodába, iskolába írassák. A község vezetőjének véleménye szerint ez a két lehetőség (helyi rendezvényeken való részvétel és a gyerekek helyi intézményekbe való beíratása), vagyis új ismerösök, barátok szerzése elősegítené a helyi közösségbe történő beilleszkedést (Király, 2018). A helyi kulturális események jelentős részének és számos egyesületi csoportnak a község központjában elhelyezkedő Faluház ad otthont, ez az épület tekinthető a helyi közösségi élét központjának is. A polgármester úr elmondása alapján ritka az olyan település, ahol annyi kulturális csoport, egyesület, rendezvény és olyan jó közösségi élet van, mint Deszken (Király, 2018).

A kutatásból származó eredmények alapján a válaszadók többsége (73\%) látogatja a helyi rendezvényeket. A helyi programokon nagyobb arányban (91\%) a településmag területén megkérdezettek vesznek részt, míg kevésbé $(55 \%)$ a lakókert lakosai. A különbséget tovább árnyalja, hogy a lakókert lakosai jellemzően olyan, nagy tömeget vonzó települési rendezvényeken jelennek meg, mint mondjuk a Majális, valamint a szeptemberben megrendezésre kerülö Falunap és az Ajvár fesztivál. Ezzel szemben a településmag lakosai sok esetben részt vesznek kisebb közösségi rendezvényeken is, tehát sokkal intenzívebben élik meg a helyi közösségi életüket. Természetesen ebböl nem az következik, hogy helyi közösséghez kevésbé kötődő lakosság nem igényli, vagy nem szokott részt venni egyéb rendezvényeken sem. Minden bizonnyal ez esetben is meghatározó Szeged közelsége, a nagyváros gazdag programkínálata és az ahhoz való szorosabb kötődésük.

A lakosok helyi civil egyesületekben, csoportokban való aktivitása igazolja, a korábban elmondottakat, ugyanis a lakókert esetén a lekérdezett háztartásokban csupán három esetben voltak tagjai valamilyen helyi civil szervezetnek, ezzel szemben a településmagban ez tíz esetben volt elmondható.

Az elözőeken kívül a szomszédsági kapcsolatok tanulmányozása is értékes információt nyújt a betelepülő lakosok beilleszkedéséröl, illetve vidéki mindennapjairól. A lakókert esetén a válaszadók $20 \%$-a nem igazán tartja a kapcsolatot szomszédjaival. Ez alatt nem feltétlen a rossz szomszédi viszonyt vagy a zárkózottságot kell érteni, hanem csupán azt az életvitelt, melyet a városból kiköltözöttek a településen is folytatnak vagy éppen azt a helyzetet, hogy a területre költözők kevésbé ismerik egymást, környezetüket. Ennek megfelelően a lakókert területére egy kevésbé intenzív szomszédsági viszony képe rajzolódik ki, nem úgy, mint a településmag területére, ahol ezek a kapcsolatok sok esetben nagyobb múltra tekintenek vissza. Következésképpen itt egyfajta belsö összetartás tapasztalható, köszönhetöen annak, hogy a szomszédsági kapcsolatok sokkal erösebbek és intenzívebbek, napi szintüek és közvetlenebbek.

A fentieken kívül még számos tényezö (település fejlettsége, a kínált szolgáltatások mennyisége és minösége, emberközpontúsága stb.) befolyásolja, hogy mennyire tudunk/akarunk beilleszkedni, illetve, hogy szeretünk-e az adott településen (településrészen) lakni vagy sem. A válaszadók többsége (79\%) szeret Deszken élni. Az „öslakosok” vagy a már régebb óta (több évtizede) a településen élők ezt nagyrészt a megszokással, rokoni és a családi kötődéssel, jó 
szomszédsággal, pezsgő kulturális élettel, kisebb részt a csendes, nyugodt környezettel vagy épp Szeged közelségével magyarázzák. Ezzel szemben a lakókert lakosai a nyugodt, csendes, tiszta és a barátságos élhetö környezetet és Szeged közelségét említik leggyakrabban. A válaszadók közül csupán ketten nem szeretnek a településen élni. Jóval többen voltak azok a válaszadók, akik az „is-is” kategóriát választották, föleg a lakókert esetén. Ez összhangban van azzal, hogy a lakókert területén élők érzik magukat (érthető módon) legkevésbé „,deszkieknek”.

Általánosságban igaz az a megállapítás, hogy egy település annál könnyebben szervezhetöbb, minél kisebbek a területi különbségek, ellentétek. Kíváncsiak voltunk, hogy a kérdőívet kitöltök, a település területén belül le tudnak-e határolni olyan településrészt, településrészeket, melyek véleményük alapján elkülönülnek. A válaszadók 79\%-a szerint beszélhetünk településen belüli területi különbségekröl. Ez legtöbb esetben (70\%) a lakókert területét jelenti, ám a településmag területéről a településhez ugyancsak szorosan kapcsolódó, attól északra fekvő zártkertes övezetet (mint egyre inkább benépesülö hétvégi házas, kiskertes területet) is megemlítik (15\%). Érdekes eredmény, hogy a lakókert területén lekérdezettek saját területüket szinte minden esetben ( $95 \%)$ megjelölik, mint elkülönülő településrészt, s más területet nem is említenek. A településmag válaszadóinak nagy része (79\%) szerint a lakókert, kisebb része (11\%) szerint a zártkertes övezet, valamint nagyjából ez utóbbival megegyezően (10\%) gondolják azt, hogy mindkét rész valamelyest elkülönül. Érdekes, hogy a lakókert lakói nagyobb arányban tekintik településrészüket elkülönülőnek, mint a településmag lakói. $\mathrm{Ez}$ alapvetöen összefügg a lakókert lakosainak zártságával, zárkózottságával, a beilleszkedés nehézségeivel, hiányával. Az elkülönülés okaként a településmag területén jellemzően a lakókert településközponttól való „nagy” távolságát, a nagy és új házait, „villáit”, valamint a fiatalabb, újgazdag, Deszkhez kevésbé kötődő (,nem is Deszkiek azok") lakosait említik.

\subsection{Szolgáltatások igénybevételének vizsgálata}

Mészáros (1994) szerint az emberek mindennapi mozgása, napi térpályája révén, jól következtethetünk az egyes csoportok életkorára, életvitelére, jövedelmi helyzetére. Ez a megállapítás fordított esetben is igaz, azaz bizonyos társadalmi csoportok életkora, jövedelmi helyzete, életvitele hatással van a napi mozgásukra, térpályájuk kialakítására. Ilyen megközelítésben, az elöbbi eredmények tükrében, feltételezhető, hogy a két településrész kapcsán különbség figyelhető meg a szolgáltatások igénybevételének helyét illetően.

Összességében elmondható, hogy a lakosok a vizsgált szolgáltatásokat és tevékenységeket legnagyobb arányban (94\%) Deszken vagy Szegeden veszik igénybe. Egyéb település (pl. Makó, Mórahalom vagy Hódmezővásárhely) csupán néhány esetben fordult elő. Ez annak tudható be, hogy bizonyos háztartások esetén, valamely dolgozó személy az előbbiekben említett települések egyikén dolgozik, $\mathrm{s}$ így ott veszi igénybe az adott szolgáltatásokat. Jelentős különbség a vizsgált területek között abból adódik, hogy a felsoroltakat Deszken vagy Szegeden veszik-e igénybe (2. táblázat). 
2. táblázat: Szolgáltatások, tevékenységek igénybevételi helyének megoszlása $(\%)$

\begin{tabular}{|c|c|c|c|}
\hline Tevékenység, szolgáltatás & igénybevétel helye & településmag & lakókert \\
\hline \multirow{2}{*}{ mindennapos bevásárlás } & Deszk & 84 & 24 \\
\hline & Szeged & 16 & 76 \\
\hline \multirow{2}{*}{ nagyobb bevásárlás } & Deszk & 16 & 0 \\
\hline & Szeged & 84 & 100 \\
\hline \multirow{2}{*}{ háziorvosi ellátás } & Deszk & 96 & 44 \\
\hline & Szeged & 4 & 56 \\
\hline \multirow{2}{*}{ gyógyszertár } & Deszk & 68 & 16 \\
\hline & Szeged & 32 & 84 \\
\hline \multirow{2}{*}{ posta } & Deszk & 81 & 56 \\
\hline & Szeged & 19 & 44 \\
\hline \multirow{2}{*}{ szépségápolás } & Deszk & 76 & 20 \\
\hline & Szeged & 24 & 80 \\
\hline \multirow{2}{*}{ testmozgás, sport } & Deszk & 45 & 10 \\
\hline & Szeged & 55 & 80 \\
\hline \multirow{2}{*}{ óvoda } & Deszk & 75 & 30 \\
\hline & Szeged & 25 & 70 \\
\hline \multirow{2}{*}{ általános iskola } & Deszk & 80 & 12 \\
\hline & Szeged & 20 & 88 \\
\hline \multirow{2}{*}{ Összességében } & Deszk & 69 & 25 \\
\hline & Szeged & 31 & 75 \\
\hline
\end{tabular}

Forrás: Kérdöíves felmérés (2018)

A lakókert Szegeddel való erős kapcsolata ez esetben is jelentős. A terület lakói a felsorolt szolgáltatásokat $75 \%$-ban a nagyvárosban veszik igénybe. Ez egyrészt adódik abból, hogy kereső lakosságának szinte teljes egésze Szegeden dolgozik. Így a mindennapi ingázás erősen hozzájárul ahhoz, hogy a felsorolt szolgáltatásokat és tevékenységeket továbbra (a kiköltözést követően) is Szegeden vegyék igénybe. Másrészt a településrész Deszken belüli földrajzi elhelyezkedése is minden bizonnyal hozzájárul a kapott eredményhez, hiszen a lakóhely és a munkahely közötti útvonal nem érinti a település központjában lévő szolgáltató helyeket (1., 3 . $a ́ b r a$ ). Harmadrészt az esetleges megszokás, vagy a nagyobb és jobb minőségü kínálat is közrejátszhat az eredmény kialakításában. Bizonyos szolgáltatások kapcsán a személyes kapcsolatok szerepe, mint például az ismeretség, a kötődés, a bizalom fontos meghatározó. Ilyen a szépségápolás területe, mely a lakókert esetén 80\%-ban ugyancsak a nagyvároshoz köthetö, annak ellenére, hogy a településen is 
számos helyen (vélhetően olcsóbban is) igénybe tudnák venni. E szolgáltatást, valamint sportot és testmozgást egyébként a településmag lakosi ugyanolyan arányban veszik igénybe Szegeden, mint Deszken. Az új településrész kapcsán kiemelendő két szolgáltatás (háziorvos, posta), ahol a többi felsorolttal szemben nem jelentkezik a város dominanciája és megközelítőleg azonos arányban veszik igénybe mindkét helyen. A lakókerthez képest a településmag esetén már nem ilyen egyöntetü az eredmény. Életkortól és jövedelmi helyzettől függően változik (mint ahogyan a lakosok napi térpályája is). Jellemzően az idősebb és kevésbé tehetősebb réteg elsősorban vagy teljes mértékben csak a községi szolgáltató, ellátó helyekre hagyatkozik. Összességében nézve a településmag területére a nagyváros dominanciája már nem kimutatható, számos szolgáltatást jellemzően helyben vagy mindkét településen megegyezö arányban veszik igénybe a lakosok. Kivételt képeznek a nagyobb bevásárlások, melyeket a lakókerthez hasonlóan nagyrészt Szegeden végeznek.

A két terület közti leginkább szembetủnő különbséget az óvoda, iskola és a mindennapos bevásárlás területén tapasztalhatunk. Ez a három terület az, amit a lakókert esetén elsősorban Szegeden, a településmag területén pedig Deszken vesznek igénybe. Természetesen ez esetben is közrejátszhat, hogy akik nap mint nap ingáznak Szeged és Deszk között, számukra praktikusabb lehet gyerekeiket a város egy óvodájába vagy iskolájába íratni (Király, 2018). Ez a jelenség, mint ahogy arról már szóltunk, sajnos nem járul hozzá ahhoz a folyamathoz, hogy a lakókert lakosai (természetesen a kivételektől eltekintve) könnyebben beilleszkedjenek a falu közösségébe.

\subsection{A lakosság vidékreprezentációjának vizsgálata}

A város környéki vidéki tér további értelmezéséhez, a lakosság vidékreprezentációját vizsgáljuk. Arra kerestük a választ, hogy milyen képek, elképzelések, asszociációk élnek a lakosság körében, ha a vidéki területekre gondolnak. Arra kértük a lakosságot, hogy szavak, kifejezések, érzések vagy asszociációk megadásával pozitív és negatív értelmezésben is jellemezzék a vidéket, továbbá kíváncsiak voltunk, hogy Deszket a vidéki területek közé sorolják-e vagy sem.

A különböző vidékképek összegzése során egyértelmüvé vált, hogy pozitív vidékkép értelmezésben több asszociáció került leírásra, mint negatív értelemben. $\mathrm{Ez}$ összességében nézve egy inkább pozitív töltetü vidékképet sugall, ami összhangban van a város környéki vidéki területeket jellemző vidékképekkel (Csurgó, 2007a).

Pozitív asszociációjú vidékképek megközelítőleg hasonló számban kerültek lejegyzésre mindkét településrészen, megoszlásukban azonban különbségek figyelhetöek meg. A vidéket a természetközeliséggel és a nyugalommal azonosító értelmezések a település teljes területén a legmeghatározóbbak közé tartoznak. Külön említést érdemel, hogy válaszadók e két értelmezést az esetek többségében első vagy második helyen említik. Az említett két asszociáción kívül, a településmag lakossága körében jellemzőek a mezögazdasági termeléshez és a falusi életvitelhez 
köthető képek (összetartozás, családias közösség, rendezett falu, kultúra ápolása) (11. ábra).

\section{1. ábra: Pozitív vidékképek megoszlása (településmag szerint rendezve)}

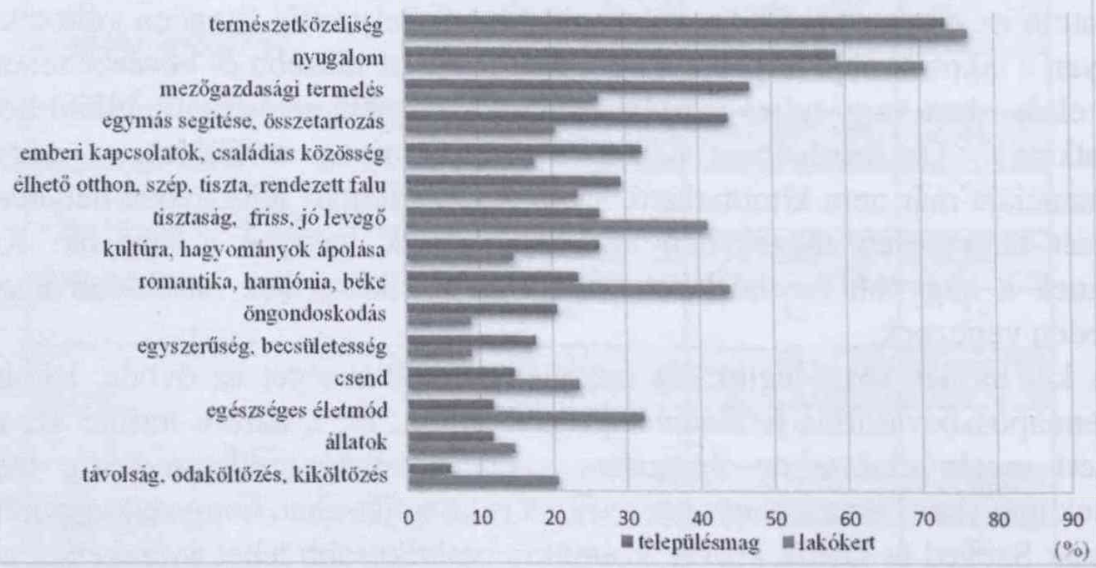

Forrás: Kérdőíves felmérés (2018)

A lakókert lakossága körében viszont a vidéki idillt szimbolizáló értelmezések (romantika, harmónia, béke, csend, egészséges életmód) jelennek meg hangsúlyosabban és csak ezt követik a mezögazdasággal, valamint a hagyományos falusi életvitellel, kapcsolatos vidékképek (12. ábra).

\section{2. ábra: Pozitív vidékképek megoszlása (lakókert szerint rendezve)}

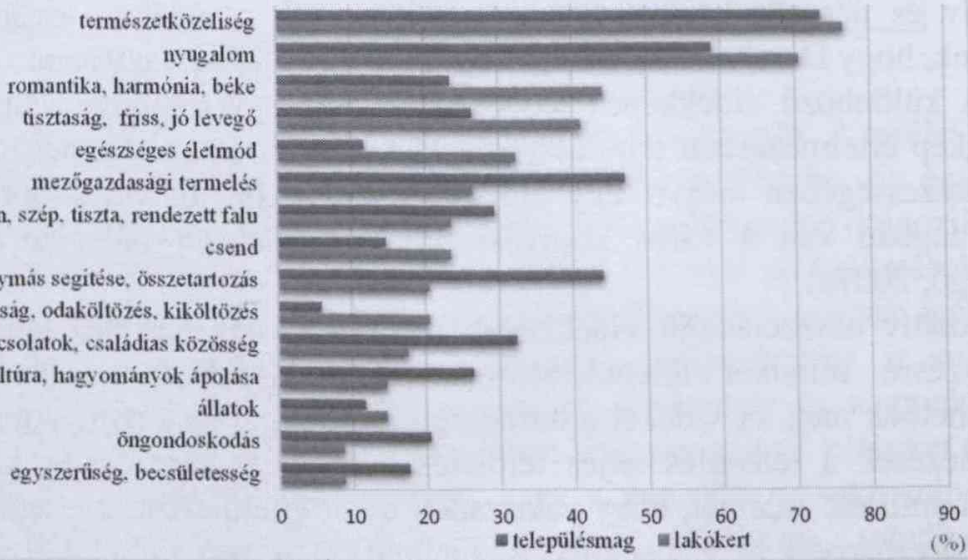

Forrás: Kérdöíves felmérés (2018) 
A negatív asszociációjú vidékképek területi összehasonlítása kapcsán elmondható, hogy a településmag területén egy pesszimistább kép rajzolódik ki, ugyanis e területen $10 \%$-al több negatív töltetű vidékkép került lejegyzésre, mint a lakókert területén (13. ábra).

\section{3. ábra: Negatív vidékképek megoszlása (településmag szerint rendezve)}

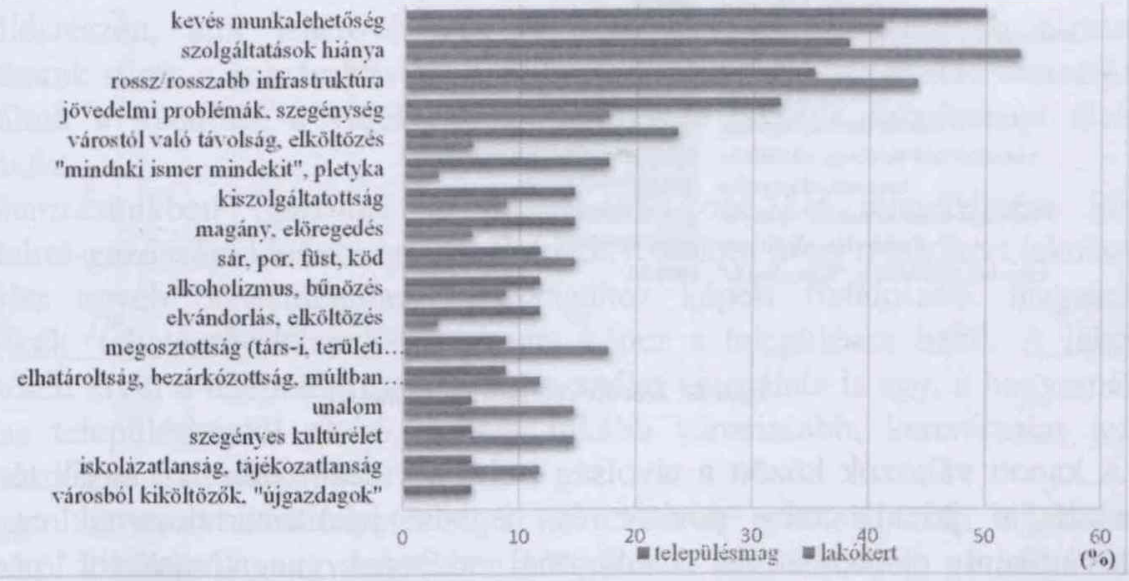

Forrás: Kérdőíves felmérés (2018)

Korábbiakhoz hasonló jelentősebb megoszlásbeli különbségek ez esetben nem mutatkoznak. Különbség viszont, hogy a lakókert területén a városiasabb igényeket kiszolgáló szolgáltatások és a megfelelő infrastruktúra hiányát tartalmazó válaszok aránya magasabb. Talán ehhez is kapcsolódóan az unalom, mint kapott válasz jellemzőbb e területen (14. ábra). 


\section{4. ábra: Negatív vidékképek megoszlása (lakókert szerint rendezve)}

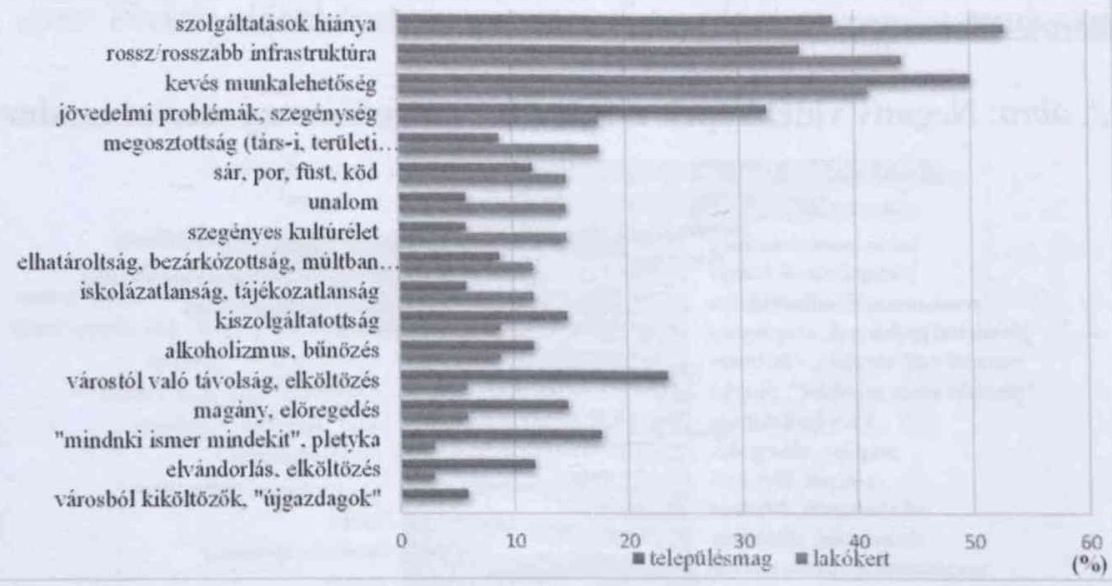

Forrás: Kérdőíves felmérés (2018)

A kapott válaszok között a távolság (mint a vidéket jellemző egyik tényező) egyedüliként jelenik meg pozitív és negatív jelentéstartalommal egyaránt. Pozitívumként elsősorban a lakókertnél szerepel, negatívumként pedig a magterületen. Pozitív értelemben a távolság jelentheti a városi gondoktól (zaj, szennyezés, zsúfoltság stb.) való távolságot, ami így kevésbé érinti a kiköltözőket, miközben a város meglehetősen közel van hozzájuk. Negatív értelemben pedig a városi funkcióktól, magasabb bérektől, jobb színvonalú szolgáltatásoktól stb. való távolságot jelentheti, ami annak ellenére fennáll, hogy a város nincs is messze tölük.

Összességében véve elmondható, hogy a hazánkra jellemző vidékkel kapcsolatos attitüdök jelentős része a deszki lakosság körében is megtalálható, amelynek egyik sajátossága a kettősség, az a kettős vidékkép (Csurgó, 2007b; Kovách, 2007), amiben egyszerre vannak jelen a romantikus, idilli, pozitívként aposztrofált elemek, illetve a vidék helyzetével, problémáival kapcsolatos negatív attitüdök és érzések. Bár mindkét településrész vizsgált lakossága körében az élményorientált (optimista) vidékkép van többségben, a lakókert kapcsán ez a kép valamivel meghatározóbb. A lakókert területére, egy kevésbé problémaorientált, a vidéket a nyugalommal, a természettel, a vidéki idillel azonosító vidékkép a jellemző; míg a településmagra a nyugalommal és a természettel kapcsolatos képek mellett a falusi élethez, a mezőgazdasághoz köthető és valamelyest pesszimistább vidékképek a jellemzőek.

\section{Konklúzió és összegzés}

A hazánkban a '90-es évek eleje óta zajló szuburbanizáció, melynek során a városi lakosság és a tevékenységek a várost övezỏ településekre települnek, átalakítja a hagyományos város-vidék kapcsolatokat, egy új, sajátos vidéki teret hozva így létre. 
Tanulmányunkban e sajátos vidéki tér elemeit, föbb jellemzöit vizsgáltuk a lakóhelyi szuburbanizáció tükrében, a szegedi nagyvárosi településegyütteshez tartozó Deszk példáján. A községben 1990 után jelentős népességszám-növekedés történt, illetve az újabb lakóterületek kijelölése révén a belteruilet is számottevően bövült. Deszk a Szegedről kiköltözők elsőszámú célterületévé vált. A népességszám jelentős bövülésének köszönheti létrejöttét a vizsgált lakókerti övezet, a Marosmenti lakókert is.

Célunk a vidéki teret meghatározó jellemzők vizsgálata volt Deszk két településrészén, ami lehetővé tette a szuburbanizáció hatásainak elemzését. Kutatásunk során a konstruktivista vidékszociológia megközelítésére támaszkodva vizsgáltuk a lokalitás, a vidékreprezentáció és a lakosok mindennapi életének jellemzöit.

Elemzésünkben igazoltuk a vizsgálatba vont két településrész közötti társadalmi-gazdasági különbségeket. Bebizonyosodott, hogy a lakókert lakossága a település egyéb belterületeinek lakosságához képest fiatalosabb, magasabban kvalifikált, tehetősebb társadalmi réteget képez a településen belül. A lakosság elemzésén kívül a településkép és a térhasználat vizsgálata is egy, a hagyományos falusias településképtől eltérö, sokkal inkább városiasabb, kertvárosias jellegü terület sajátosságait mutatja.

Igazolást nyert azon hipotézisünk is, miszerint a betelepülök, a jellemzöen Szegedröl kiköltözök, nagymértékben kötődnek a nagyvároshoz, a szolgáltatások nagy részét továbbra is korábbi lakóhelyükön veszik igénybe. Elöbbiek okán a lakókert az „alvóvárosok” tipikus jegyeit mutatja, hiszen szinte a teljes lakossága nap mint nap Deszk és Szeged között ingázik. Ezzel szemben a településmag lakossága a munkavállalással kapcsolatos napi ingázáson kívül, föként a helyben elérhető szolgáltatásokat részesíti előnyben.

A kutatás igazolta, hogy a deszki lakosok vidékképe a két településrészen eltérő. A két településrész társadalmi, térhasználati sajátosságainak megfelelöen a lakókertieket egy élményorientáltabb, a vidéki idill elemeit jobban hangsúlyozó, míg a településmagban élőket egy kevésbé élményorientált, probléma centrikusabb, a vidék elmaradottságát jobban hangsúlyozó vidékkép jellemzi.

A lakosok falusi életére, a beilleszkedésére, a település életében való részvételére jellemzö, hogy a településmag lakossága sokkal intenzívebben, a „falusi viszonyoknak megfelelöen" éli meg vidéki mindennapjait. Ezzel szemben a lakókert lakói jóval kisebb mértékben vesznek részt a helyi közösségi életben. A helyi törekvések ellenére, egy zárkózottabb, a település egészétöl és valamelyest egymástól is elkülönülő lakosság képét mutatják. 


\section{Irodalomjegyzék}

Bajmócy P. (2003): Szuburbanizáció a budapesti agglomeráción kivüli Magyarországon. Doktori értekezés. Szegedi Tudományegyetem, Szeged.

Bajmócy P. (2014): A szuburbanizáció két évtizede Magyarországon. Észak-magyarországi Stratégiai Füzetek, 11 (2): 6-17.

Csatári B. (2001): A vidék földrajzi kérdései. A földrajz eredményei az új évezred küszöbén. Magyar $\begin{array}{lllll}\text { Földrajzi Konferencia. } & \text { Szeged, 2001. } & \text { október }\end{array}$ 〈http://geography.hu/mfk2001/cikkek/Csatari.pdf〉. (2018.04.29.)

Csurgó B. (2007a): Képek és képzetek a mai magyar vidékröl. In: Kovách I. (szerk.): Vidékiek és városiak. L'Harmattan - MTAPTI, Budapest. 45-67.

Csurgó B. (2007b): Vidékképek a politikában a parlamenti beszédek tükrében. In: Boda Zs., Kovách I., Szoboszlai Gy. (szerk.): Hatalom, közbeszéd, fejlesztéspolitika: elemzések politikai jelenségekröl. MTA Politikatudományok Intézete, Budapest. 89-102.

Csurgó B. (2013): Vidéken lakni és vidéken élni. A városból vidékre költözők hatása a vidék átalakulására: a város kömyéki vidék. Argumentum Kiadó, Budapest.

Dövényi Z., Kovács Z. (1999): A szuburbanizáció térbeni-társadalmi jellemzöi Budapest környékén. Földrajzi Értesítô, 48 (1-2): 33-57.

Frumkin, H. (2002): Urban Sprawl and Public Health. Public Health Reports, 17 (3): 201-217.

Hegedüs G. (2009): A szegedi lakóparkok társadalomföldrajzi vizsgálata. Közép-Európai Közlemények, 2 (4-5): 167-174.

Király L. (2018): Szóbeli közlés

Kocsis J. B: (2000): A szuburbanizáció jelenségének főbb elméleti megközelítései a városszociológiai és más rokon tudományterületek irodalmában. Tér és Társadalom, 14 (2-3): 311-321.

Kovách I. (2007): Múlt és jelen vidékképe. Bevezetés. In: Kovách I. (szerk.): Vidék- és falukép a változó idóben. Argumentum Kiadó, Budapest. 7-11.

Kovách I. (2012): A vidék az ezredfordulón. A jelenkori magyar vidéki társadalom szerkezeti és hatalmi változásai. Argumentum Kiadó, Budapest.

KSH: Központi Statisztikai Hivatal (2014): Agglomerációk, településegyuittesek. KSH, Budapest.

KSH: Központi Statisztikai Hivatal (2018): Tájékoztatási adatbázis. Területi statisztika. Éves településstatisztikai adatok 2016-os településszerkezetben: Deszk. <http://statinfo.ksh.hu/Statinfo/haDetails.jsp?query=kshquery\&lang=hu>. (2018.03.10.)

Mészáros R. (1994): A település térbelisége. JATEPress, Szeged.

TeIR (2018): Országos Területfejlesztési és Területrendezési Információs Rendszer, Interaktív elemzö alkalmazás. Település:

Deszk <https://www.teir.hu/rqdist/main?rq_app=tdm_nd\&rq_proc=main>. (2018.02.26.)

Timár J. (1999): Elméleti kérdések a szuburbanizációról. Földrajzi Értesitō, 48 (1-2): 7-31. 